\title{
DIMENSI PEMBELAJARAN PERMAINAN KASTI BERBASIS PERKEMBANGAN MOTORIK DENGAN GAYA MENGAJAR KOMANDO PADA SISWA SEKOLAH DASAR
}

\author{
Ilham Surya Fallo ${ }^{1}$, Ardimansyah ${ }^{2}$, Netta Hidayati ${ }^{3}$ \\ ${ }^{1}$ Program Studi Penjaskesrek, Fakultas Pendidikan Olahraga dan Kesehatan, \\ IKIP PGRI Pontianak, Jln. Ampera No. 88 Pontianak \\ ${ }^{2,3}$ SD Negeri 37 Pontianak, Jln. Adi Sucipto, Gg. 777 Bangka Belitung Laut, Pontianak \\ 1email: ilhamfallo@gmail.com
}

\begin{abstract}
Abstrak
Artikel ini bertujuan untuk memberikan gambaran serta edukasi kepada guru PJOK dalam proses pembelajaran pendidikan jasmani olahraga kesehatan. Dalam proses pembelajaran pendidikan jasmani siswa sekolah dasar guru banyak menghadapi berbagai masalah pada kegiatan pembelajaran seperti fasilitas, keadaan sosial dan kebijakan pemerintah serta kebijakan sekolah yang kurang memberikan perhatian terhadap pendidikan jasmani siswa sekolah dasar. Pendidikan jasmani pada siswa di sekolah dasar sangat dibutuhkan untuk perkembangan kemampuan kognitif, afektif dan psikomotor anak dalam mempersiapkan menuju jenjang sekolah menengah pertama dan atas. Dengan demikian guru harus pandai dalam melaksanakan proses pembelajaran yang bermutu. Adapun beberapa domain yang terjadi sebagai hasil belajar yaitu; 1) keterampilan intelektual, 2) informasi verbal, 3) strategi kognitif, 4) sikap dan emosional, 5) keterampilan motorik, 6) kognitif, 7) afektif, dan 8) psikomotor. Dengan perkembangan motorik siswa tersebut akan mendukung peningkatan keterampilan gerak yang akan menjadi permanen. Salah satu materi pembelajaran yang dapat meningkatkan kemampuan motorik anak yaitu permainan kasti. Gaya mengajar komando (command) merupakan cara mengerjakan tugas dengan benar dan dalam waktu yang singkat, mengikuti semua keputusan yang dibuat oleh guru. Dengan gaya mengajar komando guru bisa membuat aktivitas dari yang sederhana ke yang sulit dari individu ke kelompok semua dilakukan dengan intruksi riang gembira dalam bentuk permainan sederhana.
\end{abstract}

Kata kunci: perkembangan motorik, komando, kasti

\begin{abstract}
This article aims to provide an overview and education to PJOK teachers in the learning process of physical sports physical education. In the process of physical education learning of elementary school students many teachers face various problems in learning activities such as facilities, social conditions and government policies as well as school policies that pay less attention to physical education of elementary school students. Physical education for students in primary school is needed for the development of children's cognitive, affective and psychomotor abilities in preparing for junior and senior high school levels. Thus the teacher must be clever in carrying out a quality learning process. As for some domains that occur as a result of learning, namely; 1) intellectual skills, 2) verbal information, 3) cognitive strategies, 4) attitudes and emotional, 5) motor skills, 6) cognitive, 7) affective, and 8) psychomotor. With the motor development of these students will support the improvement of movement skills that will become permanent. One of the learning materials that can improve children's motor skills is baseball game. The game of baseball is a traditional form of play that prioritizes some elements of compactness, dexterity and excitement. Command teaching style (command) is a way to do the task correctly and in a short time, following all the decisions made by the teacher. With the command teaching style the teacher can make activities from
\end{abstract}


simple to difficult from individual to group all done with cheerful instructions in the form of simple games.

Keywords: motor development, command, baseball

\section{PENDAHULUAN}

Pendidikan merupakan kebutuhan sepanjang hayat. Setiap manusia membutuhkan pendidikan, sampai kapanpun dan dimanapun ia berada. Pendidikan sangat penting artinya, sebab tanpa pendidikan manusia akan sulit berkembang dan bahkan akan terbelakang. Dengan demikian pendidikan harus betul-betul diarahkan untuk menghasilkan manusia yang berkualitas dan mampu bersaing, disamping memiliki budi pekerti yang luhur dan moral yang baik. Keberhasilan proses kegiatan belajar mengajar pada pembelajaran penjasorkes dapat diukur dari keberhasilan siswa yang mengikuti kegiatan tersebut. Keberhasilan itu dapat dilihat dari tingkat pemahaman, penguasaan materi, mempraktikan sendiri dan hasil belajar. Semakin tinggi pemahaman, penguasaan materi dan hasil belajar maka semakin tinggi pula tingkat keberhasilan pembelajaran. Pelakasanaan pendidikan jasmani adalah suatu proses pendidikan seseorang sebagai perorangan atau anggota masyarakat yang dilakukan secara sadar dan sistematik melalui berbagai kegiatan jasmani untuk memperoleh pertumbuhan jasmani, kesehatan dan kesegaran jasmani, kemampuan dan keterampilan, kecerdasan dan perkembangan watak serta kepribadian yang harmonis dalam rangka pembentukan manusia Indonesia berkualitas berdasarkan Pancasila. Pendidikan jasmani merupakan wahana yang mampu mendidik manusia untuk mendekati kesempurnaan hidup secara alamiah dapat memberi kontribusi nyata terhadap kehidupan sehari-hari. Secara garis besar pendidikan jasmani di Indonesia bertujuan mengembangkan individu secara organik, neuromuskuler, intelektual dan emosional. Pendidikan jasmani dapat diartikan juga sebagai suatu proses pendidikan melalui aktivitas jasmani yang didesain untuk meningkatkan kebugaran jasmani, mengembangkan keterampilan motorik, pengetahuan dan perilaku hidup sehat dan aktif, sikap sportif, dan kecerdasan emosi. Sedangkan untuk lingkungan belajar diatur secara seksama untuk 
meningkatkan pertumbuhan dan perkembangan seluruh ranah, jasmani, psikomotorik, kognitif, dan afektif setiap siswa.

Berdasarkan Komari (2017: 10), permainan untuk mengembangkan aspekaspek fisik antara lain: a) Permainan untuk meningkatkan kekuatan, misalnya untuk memperkuat otot lengan, siswa bermain basket hanya dengan melempar, satu tangan saja atau boleh dengan dua tangan, dan b) Permainan untuk meningkatkan ketangkasan sebagai contoh diberi permainan tembak menggunakan bola voli dengan sasaran tembak selain kepala dan kaki, sehingga siswa yang satu pandai menembak sasaran secara akurat sementara kawan lainnya mampu menghindar tembakan menggunakan kelincahan yang dimilikinya. Permainan merupakan salah satu dari banyak cara untuk membawa anak kepada hidup bersama dan bermasyarakat. Sebagai contoh: a) Dalam permainan anak akan memahami dan menghargai dirinya atau teman-teman sepermainannya. Pada anak yang bermain, akan tumbuh rasa kebersamaan yang sangat baik bagi pembentukan rasa sosialnya (kompetensi sosial). Anak mampu melakukan kerjasama, bantu membantu serta tolong menolong dengan sesama kawan bermainnya, b) Dalam permainan, anak akan mempunyai suasana, yang tidak hanya mengungkapkan fantasinya saja, tetapi juga akan mengungkapkan semua sifat aslinya, dan pengungkapan itu dilakukan secara patuh dan spontan. Perilaku yang ditampilkan di lapangan tidak dibuat-buat, tetapi sesuai dengan suasana batin yang bersangkutan. Dengan kata lain ketika dilapangan akan terlihat karakter aslinya. Anak laki-laki dan perempuan yang berumur sama akan berbuat yang berbeda terhadap permainan yang sama. (kompetensi pedagogi), c) Dalam permainan anak akan dibawa kepada kesenangan, kegembiraan, dan kebahagiaan dalam dunia kehidupan anak. Semua situasi ini mempunyai makna wahana pendidikan. Walaupun kalah dalam permainan namun suasana keakraban sangat kental, ketika jatuh berguling baik dirinya maupun kawannya sama-sama tertawa dan tidak ada yang bermaksud melecehkan, d) Dalam permainan, anak mengungkapkan macam-macam emosinya, dan sesuai dengan yang diperolehnya saat itu jenis emosi itu diungkapkannya, serta tidak mengarah pada prestasi. Terkadang melakukan gerakan-gerakan yang seharusnya walaupun gerakan itu 
tadi tidak dilakukan secara tepat, e) Permainan akan mendasari kerjasama, taat kepada peraturan, pembinaan watak jujur dalam bermain, dan semuanya ini akan membentuk sifat fair play (jujur, sifat ksatria, atau baik) dalam bermain. (kompetensi sosial) Misalnya ketika bermain bulutangkis dalam suatu rally shuttlecock sedikit mengenai rambut namun wasit tidak mengetahuinya, dengan penuh kesadaran menghentikan permainan dan mengaku kalau sebenarnya tadi shuttlecock telah mengenahi bagian rambutnya.

Hasil belajar adalah perubahan-perubahan yang terjadi pada diri siswa, baik yang menyangkut aspek kognitif, afektif, dan psikomotor sebagai hasil dari kegiatan belajar (Susanto, 2013: 5). Bloom dalam Rifa'i dan Catharina (2011: 8689), menyatakan bahwa hasil belajar meliputi tiga taksonomi yang disebut dengan ranah belajar. Diantaranya yaitu ranah kognitif, ranah sikap, dan ranah psikomotorik. Rinciannya sebagai berikut : a) Ranah kognitif berkaitan dengan hasil belajar berupa pengetahuan, kemampuan, dan kemahiran intelektual. Mencakup kategori pengetahuan, pemahaman, penerapan, analisis, sintesis, dan penilaian. b) Ranah afektif berkaitan dengan hasil belajar berupa perasaan, sikap, minat, dan nilai. Mencakup kategori penerimaan, penanggapan, penilaian, pengorganisasian, dan pembentukan pola hidup. c) Ranah psikomotor berkaitan dengan hasil belajar berupa kemampuan fisik seperti keterampilan motorik dan syaraf, manipulasi objek dan koordinasi syaraf. Kategori jenis perilaku untuk ranah psikomotorik yaitu persepsi, kesiapan, gerakan terbimbing, gerakan terbiasa, gerakan kompleks, penyesuaian, dan kreativitas. Ketiga ranah tersebut menjadi objek penilaian hasil belajar. Diantara ketiga ranah, ranah psikomotor adalah yang banyak dinilai karena berkaitan dengan kemampuan siswa dalam menguasai isi bahan pembelajaran. Hasil belajar afektif dan kognitif juga harus menjadi bagian dari penilaian dalam proses pembelajaran di sekolah. Beberapa pengertian di atas, dapat disimpulkan bahwa hasil merupakan perubahan perilaku seseorang yang telah mengalami proses perubahan yang sebelumnya tidak tahu menjadi tahu dan yang belum mengerti menjadi mengerti yang mana biasanya diukur dengan teknik pre test dan post test guna mengukur sejauh mana kemampuan siswa mempelajari materi yang telah dipelajari. 
Proses belajar dalam pendidikan jasmani berlangsung melalui pelaksanaan aktivitas jasmani, bermain, dan kegiatan olahraga (Depdiknas, 2003: 18). Aktivitas yang dilakukan diharapkan menjadi pengalaman belajar. Bukan sekedar gerakan badan saja tetapi mempunyai manfaat untuk mengembangkan kepribadian anak secara menyeluruh. Pengalaman belajar tersebut diharapkan dapat membantu siswa untuk menggunakan tubuhnya lebih efektif dalam melakukan gerak dasar dan keterampilan gerak. Kemampuan anak dalam menguasai kemampuan gerak yang komplek sangat ditentukan oleh kemampuan motorik. Menurut Lutan (2001: 15) mengatakan kemampuan motorik adalah kapasitas seseorang yang berkaitan dengan pelaksanaan dan peragaan suatu keterampilan yang dipelajari, sehingga akan memberi dampak pada pertumbuhan dan perkembangan anak.

Gaya mengajar yang dilakukan oleh guru dalam praktik pendidikan jasmani cenderung tradisional. Model metode-metode praktik dipusatkan pada guru (teacher centered) dimana para siswa melakukan latihan fisik berdasarkan perintah yang ditentukan oleh guru. Latihan-latihan tersebut hampir tidak pernah dilakukan oleh anak sesuai dengan inisiatif sendiri (student centered). Menurut Husdarta \& Yudha M. Saputra (2000 : 28) "gaya komando bertujuan mengarahkan siswa dalam melakukan tugas gerak secara akurat dan di dalam waktu yang singkat". Dalam proses pembelajaran penjasorkes di sekolah guru sangat terbatas dengan alokasi waktu pembelajaran yang ditetapkan sehingga sangat diperlukan inovasi dan kreatifitas guru untuk meningkatkan hasil pembelajran yang optimal sesuai alokasi waktu yang ada. Gaya mengajar komando (command) adalah untuk mempelajari cara mengerjakan tugas dengan benar dan dalam waktu yang singkat, mengikuti semua keputusan yang dibuat oleh guru. Dalam model ini semua aktivitas pembelajaran, keterlaksanaannya hanya dan sangat tergantung pada guru. Dapat dikatakan peserta didik "akan bergerak" hanya bila gurunya memerintahkannya untuk bergerak. Situasi demikian menyebabkan peserta didik pasif dan tidak diperkenankan berinisiatif. Akibatnya peserta didik tidak mampu mengembangkan kreativitas, khususnya kreativitas dalam bergerak. Hakikat: respon langsung terhadap stimulus. 
Penampilan harus akurat dan cepat. Model sebelumnya direplikasi. Gaya ini akan lebih cocok pada anak yang masih serba meniru sehingga ke depannya anak tersebut akan mampu menciptakan gerakan yang lebih baik lagi. Gaya mengajar ini lebih cocok di gunakan untuk awal pengenalan pembelajaran yang selanjutnya jika ingin melihat peningkatan guru bisa menggunakan gaya mengajar lain.

\section{PENDIDIKAN JASMANI}

Konsep umum jasmani dalam sebutan bahasa inggris adalah physical, dalam ilmu faal, jasmani disebut sebagai struktur biologik pada manusia. Secara umum dipahami bahwa jasmani atau jasa dia berarti tubuh manusia. Jasmani adalah pemanfaatan aktivitas fisik sebagai manifestasi pengembangan kualitas hidup manusia dalam memenuhi kebugaran secara totalitas dan keterampilan motorik. Jasmani disinonimkan dengan pendidikan, maka segala aktivitas jasmani membawa nilai-nilai pendidikan, yang tidak terikat ataupun tertuju kepada gerakan-gerakan dalam peraturan-peraturan dan ketentuan-ketentuan yang umum berlaku seperti olahraga. Dengan demikian, pendidikan jasmani adalah suatu proses pembelajaran melalui aktivitas jasmani yang didesain untuk meningkatkan kebugaran jasmani, mengembangkan keterampilan motorik, pengetahuan dan perilaku hidup sehat dan aktif, sikap sportif, dan kecerdasan emosi. Lingkungan belajar diatur secara seksama untuk meningkatkan pertumbuhan dan perkembangan seluruh rana, jasmani, psikomotor, kognitif, dan afektif setiap siswa. (Mahendra, 2009: 103-187).

Mulyanto, (2014: 34), pendidikan jasmani adalah proses belajar untuk bergerak, dan belajar melalui gerak. Ciri dari pendidikan jasmani adalah belajar melalui pengalaman gerak untuk mencapai tujuan pengajaran melalui pelaksanaan, aktivitas jasmani, bermain dan olahraga. Pengertian olahraga adalah proses sistematik yang berupa segala kegiatan atau usaha yang dapat mendorong mengembangkan, dan membina potensi-potensi jasmaniah dan rohaniah seseorang sebagai perorangan atau anggota masyarakat dalam bentuk permainan, perlombaan/ pertandingan, dan kegiatan jasmani yang intensif untuk memperoleh 
rekreasi, kemenangan, dan prestasi puncak dalam rangka pembentukan manusia Indonesia seutuhnya yang berkualitas berdasarkan Pancasila.

\section{PERKEMBANGAN MOTORIK}

Pada usia anak di sekolah dasar merupakan masa pertumbuhan kemampuan motorik. Menurut Yudha M. Saputra (2001: 14) anak pada usia 2-7 tahun termasuk perkembangan gerak dasar. Pada fase tersebut anak mulai belajar berjalan dan bentuk-bentuk lain gerak lokomotor. Murid-murid sekolah dasar kelas 1-3 memandang pendidikan jasmani sebagai tempat untuk berlari, memperoleh kegembiraan dan mempelajari permainan. Kelas 4-6 memandang sebagai tempat bergembira dan memperoleh keterampilan. Karakteristikkarakteristik tersebut membuat anak berkeinginan untuk berlatih memperbaiki kemampuan jasmaninya. Kemampuan itu yang membuat siswa bisa bermain dan memberikan kesempatan untuk menunjukan kebolehan pada teman-temannya. Tanpa disadari bahwa siswa sedang melatih kemampuan motorik, semakin dilatih maka kemampuannya semakin meningkat. Melalui aktivitas pendidikan jasmani peserta didik dapat meningkatkan kesegaran jasmani, keterampilan motorik, serta nilai-nilai fungsional yang mencakup kognitif, afektif, dan sosial.

Kemampuan mempelajari tugas gerak merupakan salah satu faktor mempengaruhi keberhasilan anak dalam proses pembelajaran gerak, terutama bila gerakan-gerakan yang akan dipelajari memiliki kompleksitas yang cukup tinggi. Melalui kegiatan pendidikan jasmani diharapkan anak didik dapat tumbuh dan berkembang sehat dan segar jasmaninya, serta perkembangan pribadinya secara harmoni. Kemampuan motorik merupakan hasil gerak individu dalam melakukan gerak, baik yang bukan gerak olahraga atau kematangan penampilan keterampilan gerak. Motorik adalah segala sesuatu yang ada hubungannya dengan gerakangerakan tubuh. Kemampuan motorik mempunyai pengertian sama dengan kemampuan dasar Zulkifli L (2005: 31). Gerak dasar merupakan gerak yang berkembang sejalan dengan pertumbuhan dan tingkat kematangan pada anak. Gerakan ini pada dasarnya berkembang menyertai gerakan reflek yang telah dimiliki dan disempurnakan melalui proses berlatih yang dilakukan berulang- 
ulang. Kemampuan gerak (motor ability) merupakan persepsi yang menyangkut semua modalitas persepsi, yaitu stimulus yang diterima, diteruskan ke pusat saraf atau otak untuk diintrepretasikan (Kirkendal yang dikutip oleh Jacop, 2003: 696).

Selanjutnya Rusli Lutan (1988: 96) mengatakan kemampuan motorik lebih tepat kapasitas dari seorang yang berkaitan dengan pelaksanaan dan peragaan suatu keterampilan yang relatif melekat setelah anak-anak. Pendapat lain yang dikemukakan Burton dikutip dari Jacop (2003: 697) bahwa kemampuan gerak adalah ciri umum atau kemampuan individu yang mendasari penampilan dalam berbagai keterampilan gerak. Proses belajar gerak yang bertujuan untuk menguasai gerak berlangsung dalam tiga tahap, yaitu: a) Tahap kognitif diawali dengan penerimaan informasi dan pembentukan gerak. Pada tahap ini gerakan masih kaku. Kurang terkoordinasi, kurang efisien. Pada tahap ini anak mencari bentuk gerak yang sesuai dengan dirinya. b) Tahap asosiatif pada tahap ini anakmulai mampu menyesuaikan diri dengan keterampilan yang dilakukan dan akan tampak kinerja yang dilakukan melalui terkoordinasi. Gerakan sudah mulai terlihat adanya suatu bentuk gerakan yang dilakukan dengan baik oleh anak. c) Tahap otomatisasi merupakan tahap akhir dalam belajar gerak keterampilan. Pada tahap ini anak telah memasuki tahap otomatisasi karena keterampilan gerak yang dilakukan dikerjakan secara otomatis. Usia sekolah dasar disebut juga masa intelektual, karena keterbukaan dan keinginan anak mendapatkan pengetahuan, keterampilan dan pengalaman serta sifat yang sangat khas. Magill, (1989:11) adalah berdasarkan kecermatan dalam melakukan gerakan keterampilan dibagi menjadi dua yaitu keterampilan motorik kasar (gross motor skill) dan keterampilan motorik halus ( fine motor skill). Berdasarkan awal dan berakhirnya kegiatan gerakan dibagi menajdi tiga a) Keterampilan terputus, b) Keterampilan berangkai, dan c) Keterampilan berkelanjutan. Singer (1980) Berdasarkan pengendalian stimulus irama gerak dan stabilitas lingkungan membagi menjadi Keterampilan tertutup (closed skills) dan Keterampilan terbuka (open skills). 


\section{KARATERISTIK ANAK SEKOLAH DASAR 9-10 TAHUN}

Karakteristik anak usia SD adalah senang bermain, senang bergerak, senang bekerja dalam kelompok, serta senang merasakan/melakukan sesuatu secara langsung. Oleh karena itu, guru hendaknya mengembangkan pembelajaran yang mengandung unsur permainan, memungkinkan siswa berpindah atau bergerak dan bekerja atau belajar dalam kelompok, serta memberikan kesempatan kepada siswa untuk terlibat langsung dalam pembelajaran. Menurut Rob dan Leertourwer yang dikutip oleh Sukintaka (1992: 1-44) bahwa karakteristik anak sekolah dasar dilihat secara jasmani pada umur 9-10 tahun adalah: a) Perbaikan koordinasi dalam keterampilan gerak b) Daya tahan berkembang c) Pertumbuhan tetap d) Koordinasi mata dan tangan baik e) Sikap tubuh yang tidak baik mungkin diperlihatkan f) Pembedaan jenis kelamin tidak menimbulkan konsekuensi yang besar g) Secara fisiologik putri pada umumnya mencapai kematangan lebih dulu dari pada anak laki-laki h) Gigi tetap, mulai tumbuh i) Perbedaan secara perorangan dapat dibedakan dengan nyata j) Kecelakaan cenderung memacu mobilitas.

Dengan memperhatikan segi individualitas dan karakteristik anak usia sekolah dasar serta berbagai dimensi perkembangannya, anak sekolah dasar mempunyai rasa ingin tahu yang besar terhadap segala sesuatu, baik itu yang ada pada diri mereka maupun yang berasal dari luar diri mereka. Rasa ingin tahu dari siswa yang besar ini dapat dimanfaatkan untuk membantu siswa mengembangkan bakat dan minat yang ada pada diri siswa. Dalam proses pembelajaran di sekolah dasar, rasa ingin tahu siswa yang besar ini akan sangat bermanfaat untuk meningkatkan hasil belajar siswa, dengan cara mengemas proses pembelajaran ke dalam model pembelajaran yang dapat menampung rasa ingin tahu siswa, serta mengemas materi pembelajaran ke dalam media pembelajaran yang dapat mengarahkan rasa ingin tahu siswa ke arah yang sesuai dengan tujuan dari proses pembelajaran itu sendiri. Dengan demikian diharapkan hasil belajar siswa akan maksimal. 


\section{PERMAINAN KASTI}

Kasti merupakan salah satu jenis permainan bola kecil beregu. Kasti merupakan bentuk permainan tradisional yang mengutamakan beberapa unsur kekompakan, ketangkasan dan kegembiraan. Permainan ini biasa dilakukan di lapangan terbuka, pada anak-anak usia sekolah dasar, permainan ini bisa melatih kedisiplinan diri serta memupuk rasa kebersamaan dan solidaritas antar teman. Agar dapat bermain kasti dengan baik kita dituntut memiliki beberapa keterampilan yaitu memukul, melempar, dan menangkap bola serta kemampuan lari. Kasti dimainkan oleh 2 regu, yaitu regu pemukul dan regu penjaga. Permainan kasti sangat mengandalkan kerjasama pemain dalam satu regu. Pelaksanaan permainan kasti, akan memerlukan peralatan dan juga peraturan yang akan menunjang jalannya permainannya. Adapun teknik dasar permainan permainan bola kecil kasti: a) teknik memegang bola, b) teknik melempar bola: (bola mendatar, bola melambung, bola menyusur tanah, dan bola berputar atau teknik melempar bola kepada pemukul), c) teknik menangkap bola: (dengan satu/dua tangan, dan arah datangnya bola, d) teknik memegang pemukul (dengan satu tangan dan dengan dua tangan pada rounders), e) teknik memukul bola (sikap forehand): (pukulan mendatar, pukulan melambung, pukulan merendah/menukik ke tanah, dan f) teknik berlari.

Peraturan permainan kasti sebagai berikut; a) Jumlah pemain kasti tiap regu adalah 12 orang, dengan salah satu pemain bertindak sebagai kapten. Setiap pemain wajib mengenakan nomor dada dari 1 sampai 2. b) Waktu permainan dilakukan dalam 2 babak. Tiap-tiap babak 20-30 menit. Di antara tiap babak diberikan istirahat 15 menit. c) Wasit. Pertandingan kasti dipimpin oleh seorang wasit dibantu 3 orang penjaga garis dan 1 orang pencatat waktu. pertandingan dipimpin oleh seorang wasit, dibantu oleh tiga orang sebagai penjaga garis, dan dibantu oleh seseorang sebagai pencatat nilai. Cara bermain kasti setelah kita menguasai teknik melempar, menangkap, dan memukul bola kasti, selanjutnya kita melakukan permainan bersama regu/tim. Permainan kasti ini dilakukan oleh dua regu baik putra maupun putri. Cara bermain kasti adalah: mula-mula pemain nomor 1 menuju ruang lempar kemudian ia melemparkan bola sejauh-jauhnya; 
setelah bola terlepas ia segera menuju tiang pertolongan atau langsung menuju ke tiang bebas; selanjutnya pemain nomor 2 melemparkan bola. Apabila lemparan bolanya jatuh di luar garis samping maka dinyatakan tidak sah, pemain nomor 2 hanya boleh berlari ke tiang pertolongan; setelah pemain nomor 3 melakukan lemparan dengan benar, pemain nomor 2 baru boleh berlari ke tiang bebas, sedangkan pemain nomor 1 selamat kembali ke ruang bebas maka pemain nomor 1 mendapatkan nilai/skor satu; ketika pemain nomor 2 berlari ke tiang bebas, dilempar tetapi tidak mengena sehingga pemain nomor 3 dapat kembali ke ruang bebas dengan selamat dan ia mendapat nilai/skor dua atau disebut run. Bersama dengan itu pemain nomor 2 sampai juga di ruang bebas dan ia tidak mendapatkan nilai karena melakukan lemparan yang salah. Regu Pemukul, setiap pemain berhak satu kali memukul terkecuali pemain terakhir berhak memukul sebanyak tiga kali pukulan; sesudah memukul, pemain harus meletakkan alat pemukul di dalam ruang pemukul apabila pemukul itu berada di luar pemain tersebut tidak dapat nilai terkecuali ia membetulkannya kembali. Pukulan dinyatakan benar apabila bola yang dipukul melampaui/melewati garis pukulan; selain itu saat bola dipukul, bola tidak boleh mengenai tangan dan tidak boleh jatuh di ruang bebas. Regu penjaga bertugas: mematikan lawan dengan bola yang dilambungkan; menangkap langsung bola yang dipukul; mematikan ruang bebas dengan cara menempati ruang bebas apabila jika ruang bebas itu kosong. Pelambung bertugas: melambungkan bola secara wajar sesuai dengan permintaan pemukul; jika bola yang dilambungkan tidak terpukul si pemukul harus mengulang lagi; jika sampai tiga kali berturut-turut bola tidak terpukul si pemukul dapat berlari bebas ke tiang perhentian satu. Pergantian tempat antara regu pemukul dan regu penjaga jika terjadi keadaan seperti berikut ini: salah seorang regu pemukul terkena lemparan bola; bola ditangkap tiga kali berturut-turut oleh regu penjaga; alat pemukul lepas ketika memukul; salah seorang regu pemukul ke luar dari ruang bebas atau ke luar dari batas lapangan; salah seorang regu penjaga memasuki ruang bebas atau ke luar lapangan. Nilai permainan kasti dihitung menurut peraturan sebagai berikut: pemain memukul bola berhasil berlari keperhentian I, II, III dan ruang bebas secara bertahap; pukulan dilakukan dengan benar dan dapat kembali ke ruang 
bebas tanpa berhenti pada tiang-tiang perhentian; regu penjaga berhasil menangkap langsung bola yang dipukul (bola tertangkap); pemenang adalah regu yang berhasil mengumpulkan angka/nilai terbanyak.

\section{GAYA MENGAJAR KOMANDO}

Pemakaian istilah gaya mengajar (teaching style) sering disamakan dengan istilah strategi mengajar (teaching strategy). Gaya mengajar atau strategi mengajar dimaksudkan agar siswa lebih aktif mengikuti tugas ajar dari guru. Hal ini dikaitkan dengan upaya untuk mengelola lingkungan dan atmosfir pengajaran untuk tujuan mengoptimalkan jumlah waktu aktif berlatih dari para siswa yang dipandang sebagai indikator untuk menilai efektifitas pengajaran. Untuk memahami pengertian gaya mengajar atau strategi mengajar berikut disajikan batasan-batasan dari beberapa ahli : 1). Menurut Husdarta \& Yudha M. Saputra (2000: 21) gaya mengajar merupakan interaksi yang dilakukan oleh guru dengan siswa dalam proses belajar mengajar agar materi yang disajikan dapat diserap oleh siswa. 2). Menurut Lutan (2000: 29) strategi mengajar adalah siasat untuk menggiatkan partisipasi siswa untuk melaksanakan tugas-tugas ajar.

Menurut Moston (1994: 47) Gaya Komando adalah gaya mengajar dimana siswa mengikuti semua keputusan dari pengajar. Gaya komando merupakan gaya mengajar yang menitik beratkan pada guru. Menurut Husdarta \& Yudha M. Saputra (2000 : 28) "gaya komando bertujuan mengarahkan siswa dalam melakukan tugas gerak secara akurat dan di dalam waktu yang singkat. Pada gaya komando ini, siswa harus mengikuti segala instruksi yang disampaikan oleh guru. Menurut Husdarta \& Saputra (2000: 28) dalam gaya komando peran guru sangat dominan yaitu: 1) Membuat segala keputusan dalam pembelajaran. 2) Membuat segala yang terkait dengan mata pelajaran, susunan pelaksanaan tugas, memulai dan mengakhiri waktu pelaksanaan pengajaran, interval, dan mengklarifikasi berbagai pertanyaan siswa. 3) Memberi umpan balik kepada siswa mengenai peran guru dan materi. Lazimnya, gaya itu dimuali dengan penjelasan tentang teknik baku, dan kemudian siswa mencontoh dan melakukannya berulang kali. 
Evaluasi dilakukan berdasarkan tujuan yang telah ditetapkan. Siswa dibimbing ke satu tujuan yang sama bagi semuanya. Penerapan bila gaya ini diterapkan, penjelasan disampaikan singkat dan langsung tertuju pada yang dimaksud. Tekanannya adalah pada pemberian kesempatan kepada siswa untuk berlatih sebanyak mungkin. Kekeliruan yang sering terjadi yaitu petunjuk guru terlalu rinci dan informasi terlampau banyak yang biasanya tidak dapat diingat oleh siswa. Penjelasan yang bertele-tele, perlu diganti dengan penyampaian contoh, baik sebagian maupun keseluruhan tugas gerak. Bila digunakan alat bantu, berikan kesempatan kepada siswa untuk mencobanya. Faktor keselamatan harus menjadi perhatian. Misalnya, hindari lantai atau tanah yang licin, alat yang diperikirakan bisa patah, atau objek lainnya yang dapat membahayakan siswa. Gaya ini bisa dipakai bila: a) Ingin diajarkan keterampilan khas atau hasil yang khas pula, b) Menangani kelas yang sukar dikendalikan karena kurang berdisiplin, c) Ingin dicapai kemajuan yang lebih cepat, d) Sekelompok anak memerlukan bantuan khusus untuk perbaikan. Kekurangan dari gaya komando ini adalah inisiatif sepenuhnya dipegang oleh guru. Kreativitas siswa kurang dapat terpacu.

\section{MENGAJAR YANG EFEKTIF}

Mengajar adalah membimbing siswa agar mengalami proses belajar. Dalam belajar siswa menghendaki hasil belajar yang efektif bagi dirinya. Untuk itu guru dituntut dapat membantu siswanya, sehingga pada waktu mengajar dapat dilakukan dengan efektif. Menurut Lutan, (1988: 381) efektivitas pengajaran meliputi beberapa unsur yaitu (1) pemanfaatan waktu aktif berlatih, (2) lingkungan yang efektif, (3) karakteristik guru dan siswa, (4) pengelolaan umpan balik. Diantara empat elemen tersebut elemen yang dominan pengaruhnya pada efektifitas pengajaran adalah pemanfaatan waktu aktif berlatih. Lebih lanjut Lutan (1988 : 381) mengemukakan "jumlah waktu yang dihabiskan siswa untuk aktif belajar, merupakan indikator utama dan efektivitas pengajaran”. Konsep jumlah waktu aktif berlatih erat dengan kemampuan managemen guru dalam mengelola proses belajar dan kesediaan serta ketekunan siswa untuk melaksanakan tugastugas gerak yang diajarkan. Seorang guru bertugas mengelola proses pengajaran 
berupa aktifitas merencanakan dan mengorganisasikan semua aspek kegiatan, tidak saja susunan pengalaman atau tugastugas ajar, tetapi juga penciptaan kondisi lingkungan belajar yang efektif.

Menurut Husdarta \& Saputra (2000: 4) mengemukakan: Tugas utama guru adalah untuk menciptakan iklim atau atmosfir supaya proses belajar terjadi di kelas atau lapangan. Ciri utama terjadinya proses pembelajaran adalah siswa dapat secara aktif ikut terlibat di dalam proses pembelajaran. Pada guru harus selalu berupaya agar para siswa dimotivasi untuk lebih berperan. Walau demikian guru tetap berfungsi sebagai pengelola proses belajar dan pembelajaran. Pendapat di atas menunjukkan bahwa, dalam pengaturan lingkungan belajar bertujuan agar siswa terlibat secara aktif dalam proses belajar mengajar. Seorang guru harus mampu menerapkan cara mengajar efektif.

Untuk itu guru harus memiliki beberapa kemampuan dalam menyampaikan tugas ajar, agar tujuan pengajaran dapat berhasil. Menurut Slameto (1995: 92-94) untuk melaksanakan mengajar yang efektif diperlukan syarat-syarat sebagai berikut : (1) Belajar secara aktif, baik mental maupun fisik, (2) guru harus banyak menggunakan metode pada waktu mengajar, (3) motivasi, sangat berperan pada kemajuan, perkembangan siswa selanjutnya melalui proses belajar, (4) kurikulum yang baik dan seimbang, (5) guru perlu mempertimbangkan perbedaan individual, (6) guru membuat perencanaan sebelum pengajaran, (7) pengaruh guru yang sugesif perlu diberikan kepada siswa untuk lebih giat belajar, (8) guru harus memiliki keberanian pada siswanya, juga masalah-masalah yang timbul waktu proses belajar mengajar berlangsung, (9) guru harus mampu menciptakan suasana yang demokratis. Mengajar yang efektif merupakan tuntutan yang harus dipenuhi oleh setiap guru. Syarat-syarat seperti di atas harus dipahami dan dilakukan oleh seorang guru, agar proses mengajar belajar dapat berjalan dengan baik dan memperoleh hasil belajar yang optimal. 


\section{HASIL DAN PEMBAHASAN}

\section{Dimensi Permainan Kasti Berbasis Perkembangan Motorik}

Dimensi permainan kasti berbasis perkembangan motorik adalah sebuah penerapan yang dilakukan dari tanpa bola berupa gerakan langkah kemudian dilakukan dengan bola. Bentuk gerakan lain adalah bagaimana fungsi kedua tangan bisa seirama melakukan dengan tangan kanan/kaki kanan dan tangan kiri/kaki kiri sehingga konsep pembelajaran motorik tercapai. Dalam sebuah permainan sesungguhnya koordinasi pergerakan tubuh dan koordinasi pergantian tangan akan membuat anak semakin aktif dan semakin bersemangat tanpa disadari menjadi sebuah keterampilan otomanisasi begitu pula pengendalian stimulus irama gerak dan stabilitas lingkungan berupa keterampilan tertutup (closed skills) dan keterampilan terbuka (open skills). Hasil dari penghalusan keterampilan akan terlihat pada kecermatan dalam melakukan gerakan keterampilan yaitu keterampilan motorik kasar (gross motor skill) dan keterampilan motorik halus (fine motor skill). Dengan demikian tujuan dari segi dimensi perkembangan motorik sudah tercapai, hal yang paling utama adalah bagaimana tingkat pemahaman guru dengan aktivitas gerak (movement) lebih bervariasi dimulai dari mudah ke yang sulit dan menarik untuk dilakukan baik sambil bermain atau berlomba/berkompetisi dalam membangun jiwa sportivitas anak secara individu dan tim.

\section{Rancangan Pelaksanaan Pembelajaran}

Mengajar permainan kasti dengan gaya komando yang dimaksud adalah, guru mengatur siswa sedemikian rupa agar dalam pelaksanaan pembelajaran kasti semua siswa memperoleh kesempatan melakukan tugas gerak secara merata dan dapat melakukan pengulangan gerakan sebanyak-banyaknya. Sedangkan gerak yang dimaksud adalah gerak yang terkoordinasi secara motorik. Pembelajaran permainan kasti telah direncanakan dan disusun oleh guru materi yang akan disajikan. Susunan materi pembelajaran permainan kasti dapat dilakukan dari cara yang lebih mudah yaitu tanpa menggunakan bola, baru kemudian menggunakan bola kemudian ditingkatkan secara bertahap begitu juga tangan kiri dan tangan kanan secara bergantian. Dengan menggunakan gaya komando, maka sasaran 
yang dicapai akan melibatkan siswa yang akan mengikuti petunjuk-petunjuk guru, dengan sasaran-sasaran menurut Muska Mosston (1994: 19-21) sebagai berikut: (1) respons langsung terhadap petunjuk yang diberikan, (2) penampilan yang sama / seragam, (3) penampilan yang disinkronkan, (4) penyesuaian, (5) mengikuti model yang telah ditentukan, (6) mereproduksi model, (7) ketepatan dan kecermatan respons, (8) meneruskan kegiatan dan tradisi kultural, (9) mempertahankan tingkat estetika, (10) meningkatkan semangat kelompok, (11) penggunaan waktu secara efisien, (12) pengawasan keamanan.

Pelaksanaan PJOK merupakan implementasi dari rencana pelaksanaan pembelajaran PJOK. Berdasarkan Rosdiani (2013: 55-58), proses pembelajaaran PJOK meliputi: 1) Kegiatan Pendahuluan Kegiatan pendahuluan bertujuan untuk menyiapkan siswa secara psikis dan fisik untuk mengikuti proses pembelajaran dengan menyampaikan tujuan pembelajaran dan materi yang akan dipelajari. Pembelajaran PJOK, kegiatan pendahuluan juga mencakup kegiatan warming up atau pemanasan yaitu suatu proses untuk mempersiapkan siswa baik secara fisik maupun mental dalam menghadapi materi-materi pembelajaran yang akan dipelajari dan diharapkan dapat menghindari terjadinya cedera atau rasa sakit. Prosedur warming up atau pemanasan bisa seperti berikut: Peregangan statis: berlaku untuk semua sendi dan otot. Latihan peregangan harus dilakukan dengan hati-hati agar tidak terjadi peregangan secara berlebihan. Lakukan selama kira-kia 10 menit. a) Jogging: setelah peregangan statis, lakukan jogging sekitar 500 meter. Tujuannya adalah untuk memperlancar peredaran darah, kerja jantung, dan “meringankan” pernapasan, karena jogging masuk dalam program pemanasan. b) Peregangan dinamis: urutannya adalah latihan stretching mulai dengan tubuh bagian atas terus ke bawah (top down). Jadi mulai dari leher, bahu, pundak, lengan, perut, tungkai, dan punggung. Bisa dilanjutkan dengan latihan yang agak lebih berat seperti loncat-loncat, pantul-memantul ringan (Harsono, 2017: 115116). 2) Kegiatan Inti Pelaksanaan kegiatan inti merupakan proses pembelajaran untuk mencapai kompetensi dasar yang telah ditentukan. Kegiatan inti dapat dilaksanakan dengan berbagai jenis pembelajaran seperti menggunakan permainan atau materi yang lain sesuai dengan intensitas latihan yang telah ditentukan. 
Kegiatan inti PJOK berada pada latihan yang menyebabkan denyut nadi bertambah tinggi atau bertambah pelan. Latihan atau kegiatan inti ini diatur oleh Guru sesuai dengan yang telah dipersiapkan. 3) Kegiatan Penutup Kegiatan penutup dalam pembelajaran PJOK berupa colling down atau pendinginan yang bertujuan untuk mengembalikan fungsi-fungsi tubuh ke normal secara bertahap. Pendinginan dapat dilakukan dengan latihan-latihan ringan seperti senam, jogging pelan, atau menggunakan permainan ringan (Harsono, 2017: 119). Setelah itu lakukan evaluasi pembelajaran, tutup pembelajaran, dan siswa dipersilakan untuk berganti pakaian serta kembali ke kelas. Proses pembelajaran PJOK merupakan proses pembelajaran antara Guru dan siswa yang dilaksanakan secara sistematis seperti mulai dari pemanasan, kegiatan inti, dan pendinginan sehingga siswa memahami materi baik secara teori dan praktik untuk mencapai tujuan pembelajaran. Pada prosedur warming up bisa juga dilakukan dengan stretching statis dan dinamis yang kemudian di tambah dengan gerakan berpindah atau melompat-lompat sebagai pengganti dari berlari ini mengingat waktu dan kondisi lingkungan sekolah dimana kita di tuntut untuk selalu kreatif tanpa menghilangkan sebuah tujuan pembelajaran jasmani itu sendiri.

\section{SIMPULAN}

Pembelajaran pendidikan jasmani siswa sekolah dasar dalam prosesnya guru banyak menghadapi berbagai masalah pada kegiatan pembelajaran seperti fasilitas, keadaan sosial dan kebijakan pemerintah serta kebijakan sekolah yang kurang memberikan perhatian terhadap pendidikan jasmani siswa sekolah dasar. Pendidikan jasmani pada siswa di sekolah dasar sangat dibutuhkan untuk perkembangan kemampuan kognitif, afektif dan psikomotor anak dalam mempersiapkan menuju jenjang sekolah menengah pertama dan atas. Dengan demikian guru harus pandai dalam melaksanakan proses pembelajaran yang bermutu. Adapun beberapa domain yang terjadi sebagai hasil belajar yaitu; 1) keterampilan intelektual, 2) informasi verbal, 3) strategi kognitif, 4) sikap dan emosional, 5) keterampilan motorik, 6) kognitif, 7) afektif, dan 8) psikomotor. Dengan perkembangan motorik siswa tersebut akan mendukung peningkatan 
keterampilan gerak yang akan menjadi permanen. Salah satu materi pembelajaran yang dapat meningkatkan kemampuan motorik anak yaitu permainan kasti. Permainan kasti merupakan bentuk permainan tradisional yang mengutamakan beberapa unsur kekompakan, ketangkasan dan kegembiraan. Dengan materi tersebut guru perlu menggunakan metode atau gaya mengajar yang cocok sehingga proses pembelajaran tercapai dengan menggunakan gaya mengajar komando. Gaya mengajar komando (command) merupakan cara mengerjakan tugas dengan benar dan dalam waktu yang singkat, mengikuti semua keputusan yang dibuat oleh guru. Dengan gaya mengajar komando guru bisa membuat aktivitas dari yang sederhana ke yang sulit dari individu ke kelompok semua dilakukan dengan intruksi riang gembira dalam bentuk permainan sederhana. Dengan demikian pada materi permainan kasti guru harus memperhatikan perkembangan motorik siswa secara keseluruhan dengan gaya mengajar komando. Salah satu contoh pembelajaran keterampilan motorik pada materi permainan kasti dengan gaya mengajar komando akan memberikan dampak positif pada anak yang sudah mulai terampil melakukan lempar tangkap baik dengan tangan kanan dan dengan tangan kiri serta sudah bisa mengaplikasikan baik individu maupun berkelompok. Basic skiil pada anak akan bersifat otomanisasi jika sudah di terapkan guru sejak usia dini atau sekolah dasar yang kemudian akan di aplikasikan dengan cabang olahraga lain ketika menuju sekolah menengah pertama. Dengan koordinasi gerak yang terampil, baik dan benar anak akan terhindar dari cedera bahkan akan mengalami pertumbuhan sesuai fase umurnya. Hasil akhir dari aplikasi perkembangan motorik anak adalah menjaga mereka untuk menjadi anak yang sehat jasmani terhindar dari obesitas, tingkah laku negatif di masyarakat dan menyiapkan mereka untuk berkompetisi secara Nasional dan Internasional.

\section{DAFTAR PUSTAKA}

Depdiknas. (2003). Undang-undang RI no.20 tahun 2003 tentang sistem pendidikan nasional. Jakarta: Depdiknas.

Harsono. (2015). Kepelatihan olahraga. Bandung: PT. Remaja Rosdakarya. 
Lutan, R. (1988). Belajar keterampilan motorik pengantar teori dan metode. Jakarta: P2LPTK Ditjen Dikti Depdikbud.

Lutan, R. (2002). Pendidikan kebugaran jasmani: orientasi pembinaan di sepanjang hayat. Jakarta: Dirjen Pendidikan Dasar dan Menengah Dirjen OR.

Magill, R., A. (1980). Motor learning, concepts and application. Dubuqua, Iowa: WM.C. Brown Publisher.

Mahendra, A. (2009). Asas dan falsafah pendidikan jasmani. Bandung: FPOK UPI.

Mosston, M. \& Ashworth, S. (1994). Teaching physical education. Mac Millan College Publishing Company, Inc. USA.

Komari, A. (2010). Biomekanika olahraga. Yogyakarta: UNY Press.

Rifa'i, A. \& Anni, C. (2011). Psikologi pendidikan. Semarang: Universitas Negeri Semarang.

Singer, R., N. (1980). Motor learning and human per-formance. New York: Macmillan Publishing Company.

Slameto. (2010). Belajar dan faktor-faktor yang mempengaruhinya. Edisi revisi. Jakarta: Rineka cipta.

Sukintaka. (1992). Teori bermain untuk D2 PGSD penjaskes. Proyek Pembinaan dan Peningkatan Mutu Tenaga Kependidikan Direktorat Jenderal Pendidikan Tinggi. Jakarta: Departemen Pendidikan dan Kebudayaan.

Zulkifli, L. (2003). Psikologi perkembangan. Bandung: Remaja Rosda Karya. 